\title{
NEPŘÍZNIVÉ ASPEKTY PROCESU OBNOVY NEMOVITÝCH PAMÁTEK Z HLEDISKA ZÁVAZNÉHO STANOVISKA ORGÁNU PAMÁTKOVÉ PÉČE A DÉLKY SPRÁVNÍHO ŘíZENÍ
}

\section{UNFAVORABLE ASPECTS OF THE ADMINISTRATIVE PROCESS OF THE RECONSTRUCTION OF HISTORIC BUILDINGS}

\author{
Michal Vondruška \\ Tencalla, Brigadnicka 276/73H, Mokra Hora, 62100 Brno, Czech Republic \\ michal.von@email.cz, +420733530102
}

\begin{abstract}
Abstrakt - CZ
V České republice se nachází velké množství kulturních památek a historických budov. Pro jejich zachování existuje velmi př́sná legislativa. Ukazuje se však, že tyto předpisy $v$ kombinaci se stavebním a správním řádem jsou pro vlastníky památek velmi komplikované a v některých prípadech mohou být vzhledem $\mathrm{k}$ ochraně památek $\mathrm{i}$ kontraproduktivní. Článek je zaměřen na nepříznivé aspekty procesu obnovy nemovitých památek z hlediska odpovědnosti za obsah stavebnětechnologických pokynů ve vydaných stanoviscích orgánů památkové péče a délky správního řízení.

Klíčová slova - CZ

Památková péče, správní řízení, obnova památek

\section{Abstract - EN}

There are a significant number of cultural monuments and historical buildings in the Czech Republic. There is very strict legislation to preserve them. It turns out, however, that these rules, in combination with building and administrative regulations, are very complicated for owners and in some cases, they may also be counterproductive due to the protection of monuments.

The article focuses on the unfavorable aspects of the process of restoration of immovable monuments in terms of responsibility for the content of building and technological guidelines in the issued opinions of the authorities of monument care and the length of the administrative proceedings.
\end{abstract}

\section{Keywords - EN}

Monument care, Administrative proceedings, Restoration of monuments

JEL Classification

O18 - Urban, Rural, Regional, and Transportation Analysis, Housing, Infrastructure L74 - Construction

DOI: https://doi.org/10.14311/bit.2017.02.05

Editorial information: journal Business \& IT, ISSN 2570-7434, CreativeCommons license (c) (1) published by CTU in Prague, 2017, http://bit.fsv.cvut.cz/ 


\section{Úvod}

Proces obnovy nemovitých kulturních památek v České republice podléhá ustanovením stavebního zákona [1] (Zákon č. 183/2006 Sb.), památkového zákona [2] (č. 20/1987 Sb.) a správního raádu [3] (Zákon č. 500/2004 Sb.).

Stanovené postupy podle druhé části stavebního zákona upravují v $\$ 4$ výkon veřejné správy $v$ konkrétních činnostech úřadů památkové péče, které se nacházejí v postavení dotčeného orgánu státní správy. Mezi tyto činnosti patří $v$ procesu stavebního řízení vydání závazného stanoviska dotčeného orgánu, které vymezuje podmínky pro provedení konkrétní stavby. Orgány památkové péče, které jsou zřízeny Ministerstvem kultury za účelem ochrany kulturního dědictví, mají ve svých stanoviscích zohledňovat především zájem o zachování historických hodnot nemovitostí.

Zájmy vlastníka nemovitosti při obnově památky jsou reprezentovány snahou o co největší efektivitu v oblasti rychlosti výstavby, finančních nákladů obnovy, funkčních a estetických požadavků a kvalitativních požadavků na výstavbu podle současných standardů, které umožní pozdější bezproblémového užívání opravené nemovitosti.

V praxi však požadavky formulované $v$ závazných stanoviscích orgánů památkové péče nejsou vždy v souladu s principy památkové ochrany a zároveň nerespektují zájmy vlastníka nemovitosti.

Cílem tohoto článku je a analyzovat některé nedostatky $v$ procesu stavebního řízení při opravách nemovitých památek a nepřiznivých aspektů obsahu závazných stanovisek orgánů památkové péče, které neřeší stávající platná [4] i připravovaná legislativa [5].

\section{Organizační uspořádání státní památkové péče $\mathbf{v}$ České republice}

V České republice vykonávají podle památkového zákona [2] správu kulturních památek: orgány státní památkové péče, jimiž jsou ministerstvo kultury, krajské úřady a obecní úřady obcí s rozšířenou působností a odborné organizace, kterými jsou územní odborné pracoviště Národního památkového ústavu (dále jen NPU), podřizené Ministerstvu kultury. Ústřední dozor nad dodržováním tohoto památkového zákona [2] a předpisů vydaných $\mathrm{k}$ jeho provedení vykonává památková inspekce, zř́zená Ministerstvem kultury.

\section{Proces vydání stavebního povolení při obnově nemovitých památek}

Podle $\$ 110$ stavebního zákona [1], odstavce $2 \mathrm{~d}$ musí stavebník k žádosti o stavební povolení připojit mimo jiné i závazná rozhodnutí dotčených orgánů nebo jiné doklady vyžadované zvláštními právními předpisy.

\section{1/ Závazné stanovisko orgánu památkové péče}

Jestliže vlastník nemovité památky (nebo stavby v památkově chráněném území) plánuje provést údržbu, opravu, rekonstrukci, restaurování nebo jinou úpravu nemovité památky nebo jejího prostředí (dále jen „obnova“), je povinen ve smyslu památkového zákona [2] si předem vyžádat závazné stanovisko orgánu památkové péče, tedy obecního úřadu obce $s$ rozšiřrenou působností, a jde-li o národní kulturní památku, závazné stanovisko krajského úřadu.

$\checkmark$ závazném stanovisku se orgán památkové péče má vyjádřit, zda plánované práce tam uvedené jsou z hlediska zájmů státní památkové péče př́ipustné, a stanoví se základní podmínky, za kterých lze tyto práce připravovat a provést.

Základní podmínky musí podle památkového zákona [2] vycházet ze současného stavu poznání kulturně historických hodnot, které je nezbytné zachovat při umožnění realizace zamýšleného záměru. 
Souhlas je nutný pro všechny stupně povolovacího řízení a to i pro stavby, které podléhají podle stavebního zákona [1] pouze ohlášení.

Lhůta pro vydání závazného stanoviska je podle $§ 49$ správního rádu [3] stanovena v jednoduchých věcech bezodkladně do 30 dnů od zahájení rízení, ve zvlášt složitých prípadech do 60 dnů.

\section{2/ Podmiňující vyjádření odborné organizace památkové péče a/ Vyjádření odborné organizace pro závazné stanovisko}

Př́slušný orgán památkové péče vydává závazné stanovisko podle památkového zákona [2] až po předchozím písemném vyjádření odborné organizace památkové péče, se kterou má rovněž na její žádost projednat ještě před ukončením řízení návrh tohoto závazného stanoviska.

Podle památkového zákona [2] předloží odborná organizace státní památkové péče písemné vyjádření př́slušnému orgánu státní památkové péče nejpozději ve Ihưtě 20 dnů ode dne doručení žádosti o jeho vypracování, nestanoví-li orgán státní památkové péče ve zvlášt́ složitých případech Ihůtu delší, která nesmí být delší než 30 dnů. Pokud ve Ihůtě 20 dnů nebo v prodloužené lhůtě příslušný orgán státní památkové péče písemné vyjádření neobdrží, vydá závazné stanovisko bez tohoto vyjádření.

\section{b/ Vyjádření odborné organizace $k$ projektové dokumentaci stavby}

Dalším závazkem pro vlastníka nemovité památky, který plánuje její obnovu je podle památkového zákona [2] nařizení, podle kterého musí vlastník nebo projektant přípravnou a projektovou dokumentaci obnovy nemovité kulturní památky projednat $v$ průběhu zpracování $s$ odbornou organizací státní památkové péče z hlediska splnění podmínek závazného stanoviska orgánu památkové péče.

Při projednávání poskytuje odborná organizace státní památkové péče potřebné podklady, informace a odbornou pomoc.

Ke každému dokončenému stupni projektové dokumentace zpracuje odborná organizace státní památkové péče písemné vyjádření jako podklad pro závazné stanovisko obecního úřadu obce $\mathrm{s}$ rozšířenou působností, jde-li o nemovitou národní kulturní památku, jako podklad pro závazné stanovisko krajského úřadu.

\section{3/ Stavební povolení}

Po obdržení všech př́slušných rozhodnutí orgánů státní správy pak stavební úřad podle $\$ 111$ Stavebního zákona[2] přezkoumá podanou žádost a připojené podklady z toho hlediska, zda stavbu Ize podle nich provést, a ověří zejména, zda je projektová dokumentace úplná, přehledná a zda jsou v odpovídající míře řešeny obecné požadavky na výstavbu a předložené podklady vyhovují požadavkům uplatněným dotčenými orgány.

Stavební úřad ověři rovněž účinky budoucího užívání stavby a další formální úkony podle §112-114 stavebního zákona a vydá stavební povolení.

$\checkmark$ jednoduchých věcech, zejména Ize-li rozhodnout na základě dokladů předložených stavebníkem, má rozhodnout stavební úřad bez zbytečného odkladu, nejdéle však ve Ihůtě do 60 dnů ode dne zahájení stavebního řízení; ve zvlášt́ složitých případech stavební úřad rozhodne nejdéle ve lhůtě do 90 dnů.

\section{Nepříznivé aspekty obnovy nemovitých památek}

Stavební zákon i památkový zákon jsou jako samostatné předpisy v oblasti ochrany nemovitých památek velmi podrobně zpracovány. Spolu se správním řádem však netvoří kompaktní útvar, podle kterého by se mohly státní úřady jednoznačně a rychle rozhodovat. Jak ukazuje praxe, tak i samotné dvojkolejné rozhodování orgánů a organizací památkové péče může způsobovat majitelům památkových nemovitostí při realizaci a následném užívání stavby celou řadu problémů. 


\section{1/ Prodražení a prodloužení lhůt projektové dokumentace}

Projektová dokumentace obnovy nemovité památky musí být podle památkového zákona postupně předem schválena organizací památkové péče reprezentované územními odbornými pracovišti Národního památkového ústavu (NPÚ) a jejími odbornými garanty. Projektanta si sjednává a platí vlastník nemovitosti. Projektant však musí bez výhrad na náklady vlastníka zapracovat připomínky odborného garanta NPÚ do všech stupňů projektové dokumentace, aby mohla následně být odsouhlasena i orgánem památkové péče $v$ jeho závazném stanovisku, přičemž sám nese odpovědnost za správnost dokumentace. Odborný garant a NPÚ Organizace památkové péče podléhá ministerstvu kultury a nařizuje úpravy projektové dokumentace pouze z hlediska svých profesních zájmů. Odborný garant památkového ústavu, který se k dokumentaci vyjadřuje a ani není př́mým účastníkem stavebního řízení, nenese žádnou odpovědnost za správnost svých rozhodnutí.

Zde je třeba připomenout, že odborní garanti jsou kvalifikováni především v oblasti historie a $v$ uměleckých oborech[10], takže otázka technologické kvality projektu jde často stranou.

Pokud je dokumentace předkládána ke schválení ještě před zahájením stavebního řízení, není odborný garant vázán žádnými lhůtami.

Náklady na realizaci a doba zpracování projektové dokumentace rostou sčasem schvalovacího procesu a přepracováním návrhů.

K zefektivnění komunikace a zrychlení povolovacího procesu by jistě přispělo zavedení elektronického podání všech stupňů projektové dokumentace

\section{2/ Prodloužení lhůt pro vydání závazného stanoviska orgánu památkové péče}

Jednou z věcí, se kterou se majitelé památek nejčastěji potýkají při stavebním řízení a která je velmi často odrazuje od záměru realizace i drobných provozních oprav je velmi zdlouhavé vyřizování potřebných podkladů pro ohlášku stavby nebo stavební povolení. Podle stavebního i památkového zákona musí stavebník žádat o stavební povolení i u velmi jednoduchých úprav či změn jako jsou např. výměny podlahové krytiny, úprava osvětlení apod.

Organizacemi památkové péče jsou územní pracoviště Národního památkového ústavu (NPÚ), které jsou zastoupeny odbornými garanty. Kapacitní obsazení NPÚ odbornými garanty je i přes velký počet nemovitých památek v ČR nedostatečné. Stejné kapacitní omezení je i v orgánech památkové péče, kterými jsou památkové odbory na stavebních úřadech s rozšířenou působností.

Instituce památkové péče, které se musí k záměru vyjadřovat, rozhodují samostatně někdy i rozdílně. Vyjádření organizace památkové péče (NPÚ) je podkladem pro vydání stanoviska orgánu památkové péče.

Problémy nastávají i v okamžiku, kdy některé jiné dotčené orgány státní správy mají vlastní požadavky na provedení stavby, které může být $v$ rozporu s již předjednanou projektovou dokumentací a to i v drobném detailu. (Délka komína, odvětrání budovy, požadavky na osvětlení, bezbariérový přístup apod.) Vzhledem $k$ absenci elektronické výměny dat, nedostatečném personálním obsazení jednotlivých orgánů a organizací státní správy a nejednoznačnosti jednotlivých stanovisek dotčených orgánů pak př́pravu samotných podkladů pro vydání stavebního povolení může prodloužit o několik měsíců.

Z těchto důvodů bývá zákonem stanovená lhůta pro vyřízení závazného stanoviska orgánu památkové péče $v$ jednoduchých prípadech okolo 60 dní a ve složitějších prípadech překročena. Stavebník tyto Ihůty nemůže ovlivnit a má jen velmi omezené možnosti ochrany svých zájmů.

Možným řešením této situace by mohla být reorganizace systému památkové péče v České republice podle některých zahraničních vzorů např. bavorského či slovenského systému nebo úprava rozsahu rozhodování a kompetencí institucí památkové péče v současném systému. Jistě Ize určit kategorie staveb a podmínky provádění zásahů do nemovitých památek, které nevyžadují vyjádření organizace památkové péče. (např. Změny v přístavbách, výměna nepůvodních dveří, vypínačů, osvětlení, těles ústředního topení, podlahových krytin, zásahy do vnitřních prostor prístavby k nemovité památce apod.) U jednoduchých úprav, které nyní podle stavebního zákona vyžadují úplné stavební řízení 
včetně rozsáhlé projektové dokumentace a stanovisek všech orgánů, by se mohlo při zvýšení rozhodovacích kompetencí orgánů památkové péče uvažovat o zjednodušení tohoto procesu.

\section{3/ Neodbornost obsahu závazného stanoviska orgánu památkové péče z hlediska současných stavebních technologií, které zachovají památkovou hodnotu stavby}

Z hlediska stavebně technické ochrany nemovité památky je nejdůležitější kvalitní návrh obnovy památky a kvalita posouzení požadovaných prací odborným garantem NPÚ. Vyjádření k záměru obnovy je podkladem pro podmínky závazného stanoviska orgánu památkové péče. Jak je žrejmé ze závěrů kontrol závazných stanovisek prováděných Památkovou inspekcíi pracovníci orgánů památkové péče beze zbytku akceptuji do svých rozhodnutí podmínky vyjádření garantů NPU i když nejsou jejich požadavky opodstatněné $z$ hlediska Památkového zákona a prováděcích předpisů $[7,8,9]$ Stavebního zákona.

Zde je opět zřejmý nedostatek v kvalifikaci pracovníků NPU[10] ve stavebních oborech a svázanost pracovníků stavebních úřadů formálním dodržení stanovených postupů, časových a kapacitních možností.

\section{Př́klad z praxe}

Záměrem městského investora bylo předláždění historické ulice žulovou dlažbou. Pověřený projektant konzultoval v průběhu zpracování projektové dokumentace navrhované rešení s garantem NPU. Garant NPU, nařídil odstranit z návrhu drenážní nopovou folii, která zabraňuje vzlínání vody z podkladních vrstev dlažby do fasád domů přimknutých ke komunikaci. Toto řešení zdůvodnil tím, že detail styku dlažby s fasádou domu a drenážní folií nebývá při realizaci dodržen a z estetického a historického hlediska je případně vyčnívající folie nepř́pustná. $V$ tomto ohledu měl garant jistě pravdu, bylo však jeho povinností zajistit dohled nad technologickou kázní dodavatelské firmy. Namísto toho byla provedena dlažba způsobem, který v okamžitém efektu byl z estetického hlediska působivý, ale následky vzlínající vody poškozují fasády historických domů v místě nového předláždění. Vznikají tak škody nejen z pohledu ochrany památek, ale i ekonomické škody majitelům památkových budov, kteří s realizací dlažby nemají nic společného. Jeden z majitelů sousedních objektů provedl $\checkmark$ rámci obnovy fasády, která probíhala zároveň s předlážděním folii vlastním nákladem v rozporu se závazným stanoviskem orgánu památkové péče a vyjádření NPÚ podle původního detailu. Vlhkost z podloží žulové dlažby na tomto objektu nevzlíná, estetické i historické hodnoty zůstaly zachovány. Stav fasády je patrný z obr. 1,3,5. Doporučení odborného garanta NPU a vydané závazné rozhodnutí tedy bylo chybné. Památka nebyla chráněna, ale došlo $\mathrm{k}$ jejímu poškození. 


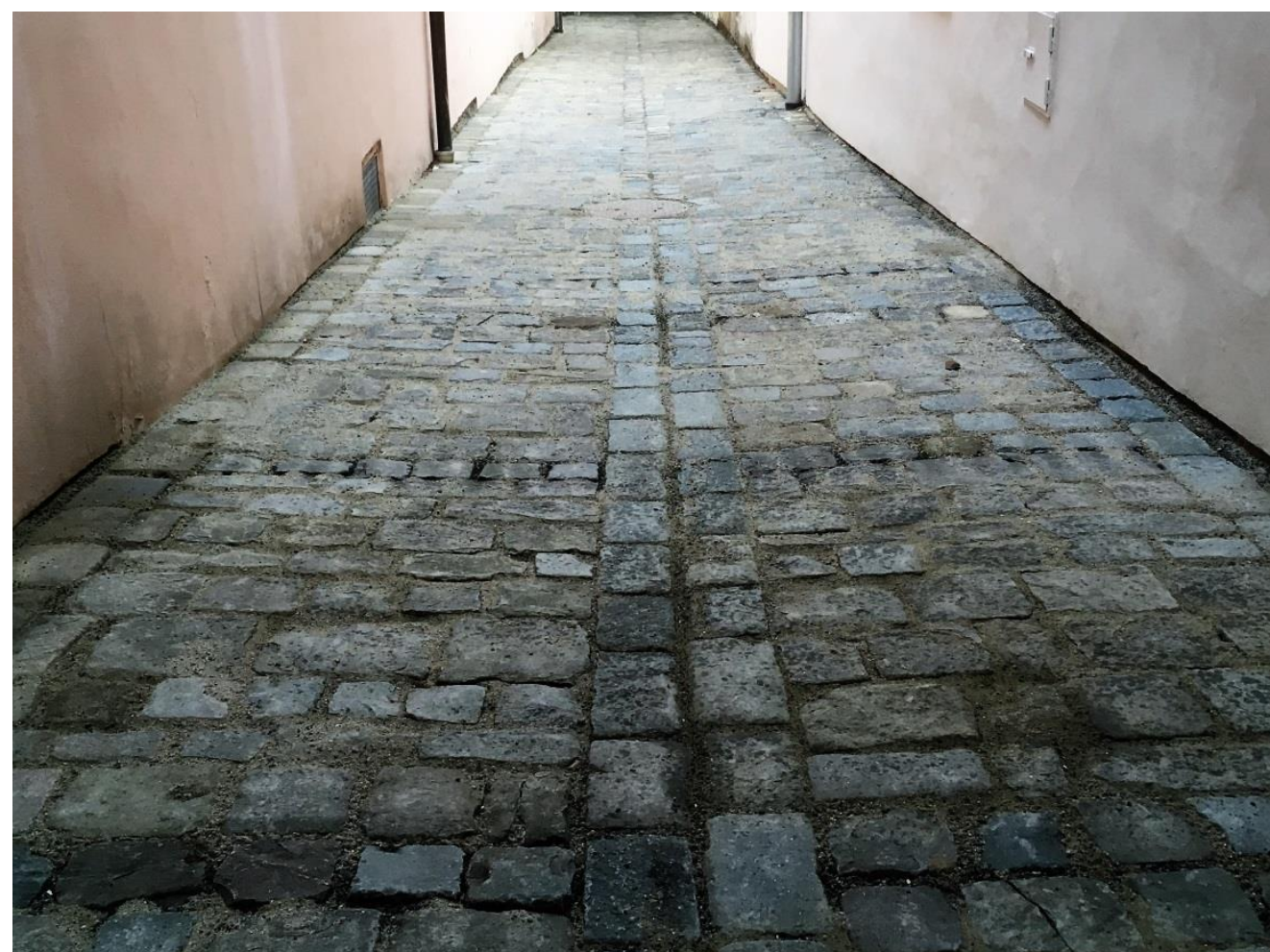

Obrázek 1: Stav předlážděné ulice. Pravá strana s použitím nopové folie, levá strana bez folie. (zdroj: autor)
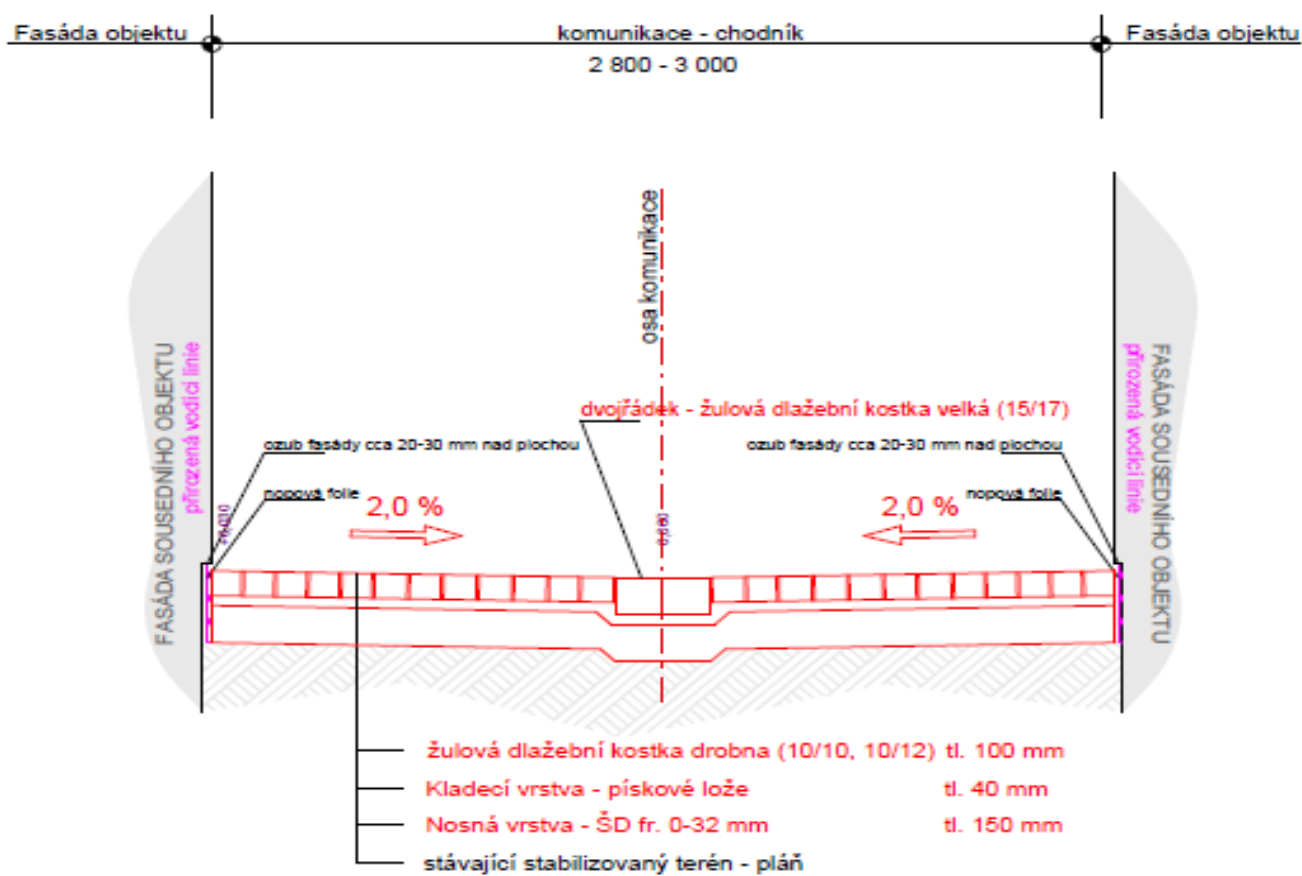

Obrázek 2: Původní projektová dokumentace. Příčný řez, detail s použitím nopové folie. (zdroj: autor) 


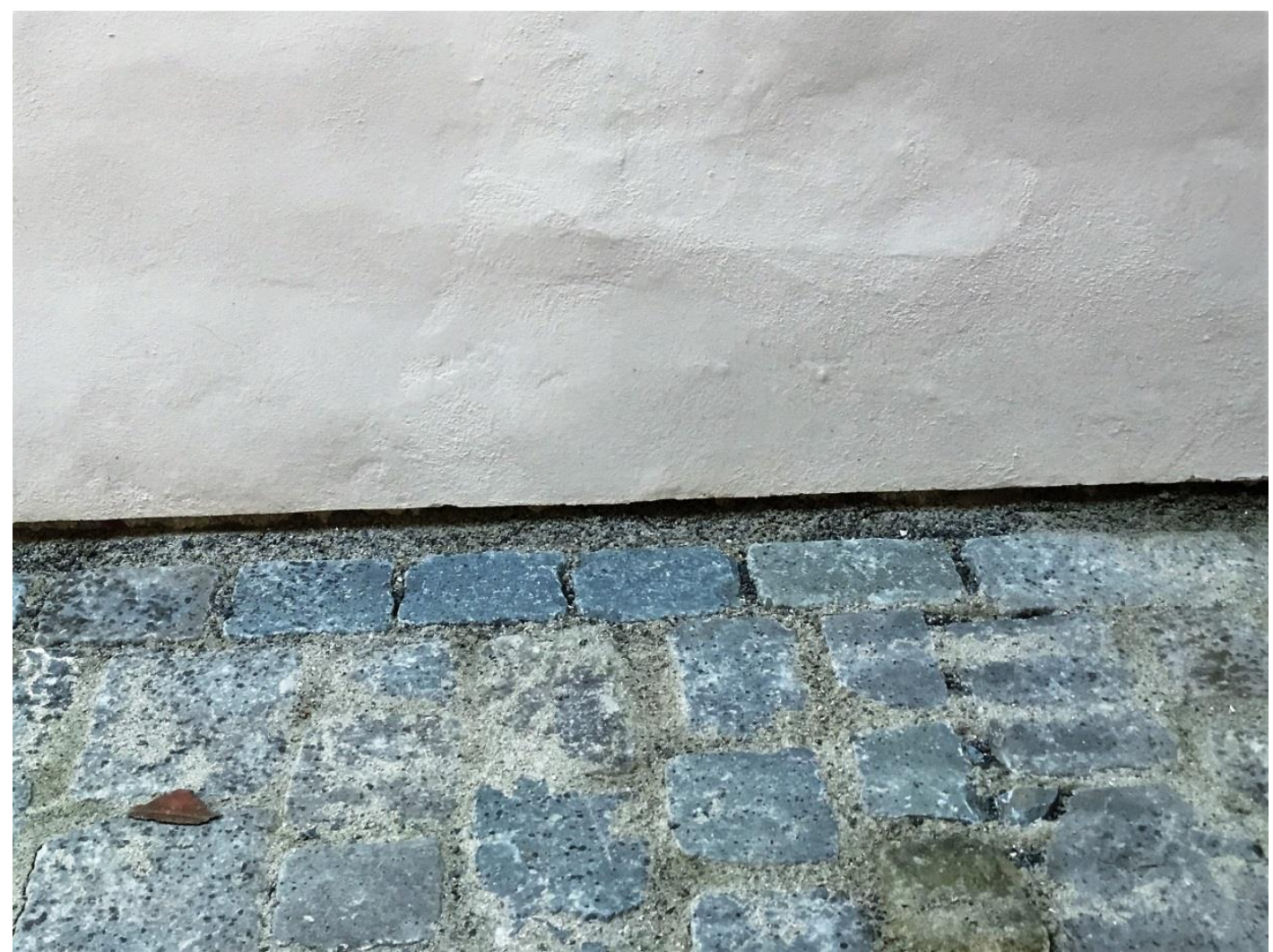

Obrázek 3: Detail fasády domu s použitím nopové folie ve styku s dlažbou. (zdroj: autor)
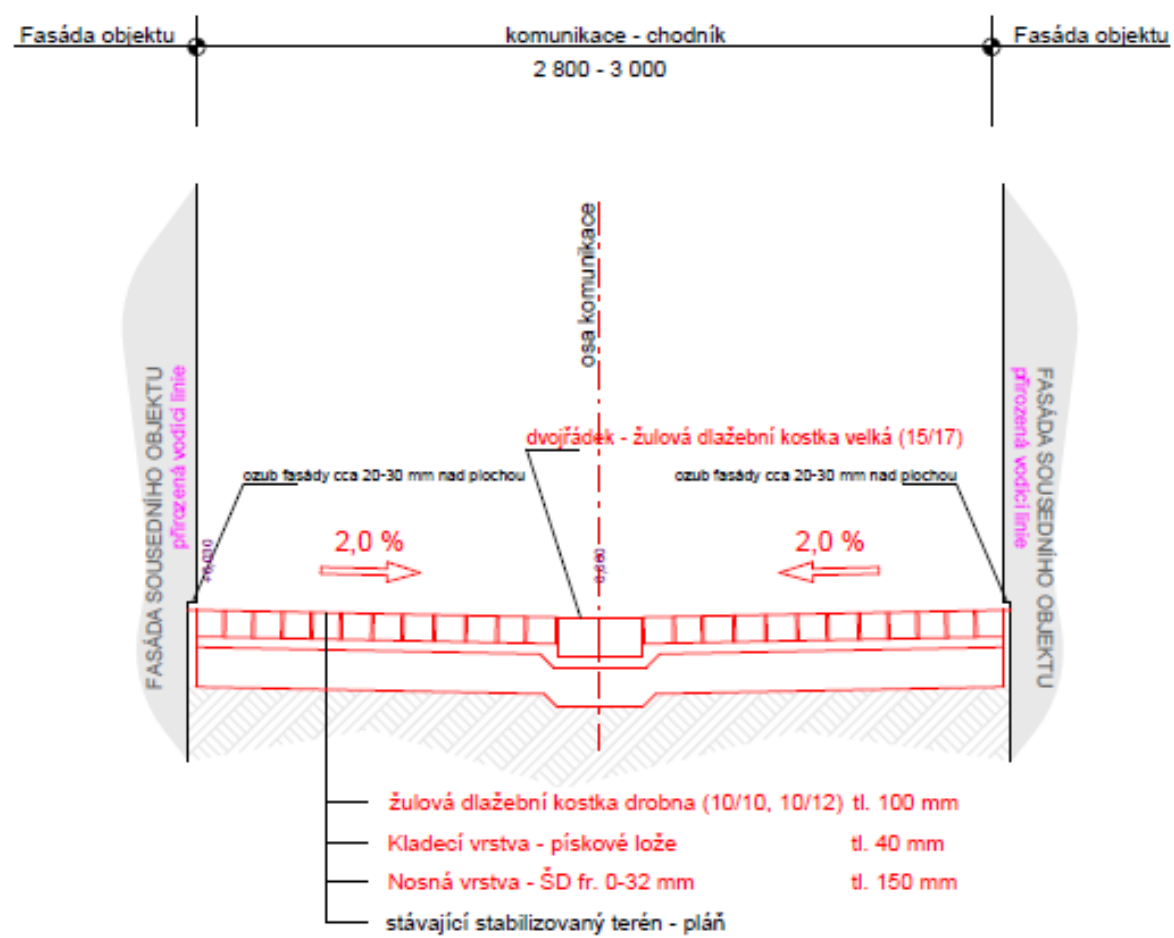

Obrázek 4: Projektová dokumentace upravená podle pokynů garanta NPU. Př́ičný řez, detail s použitím nopové folie. (zdroj: autor) 


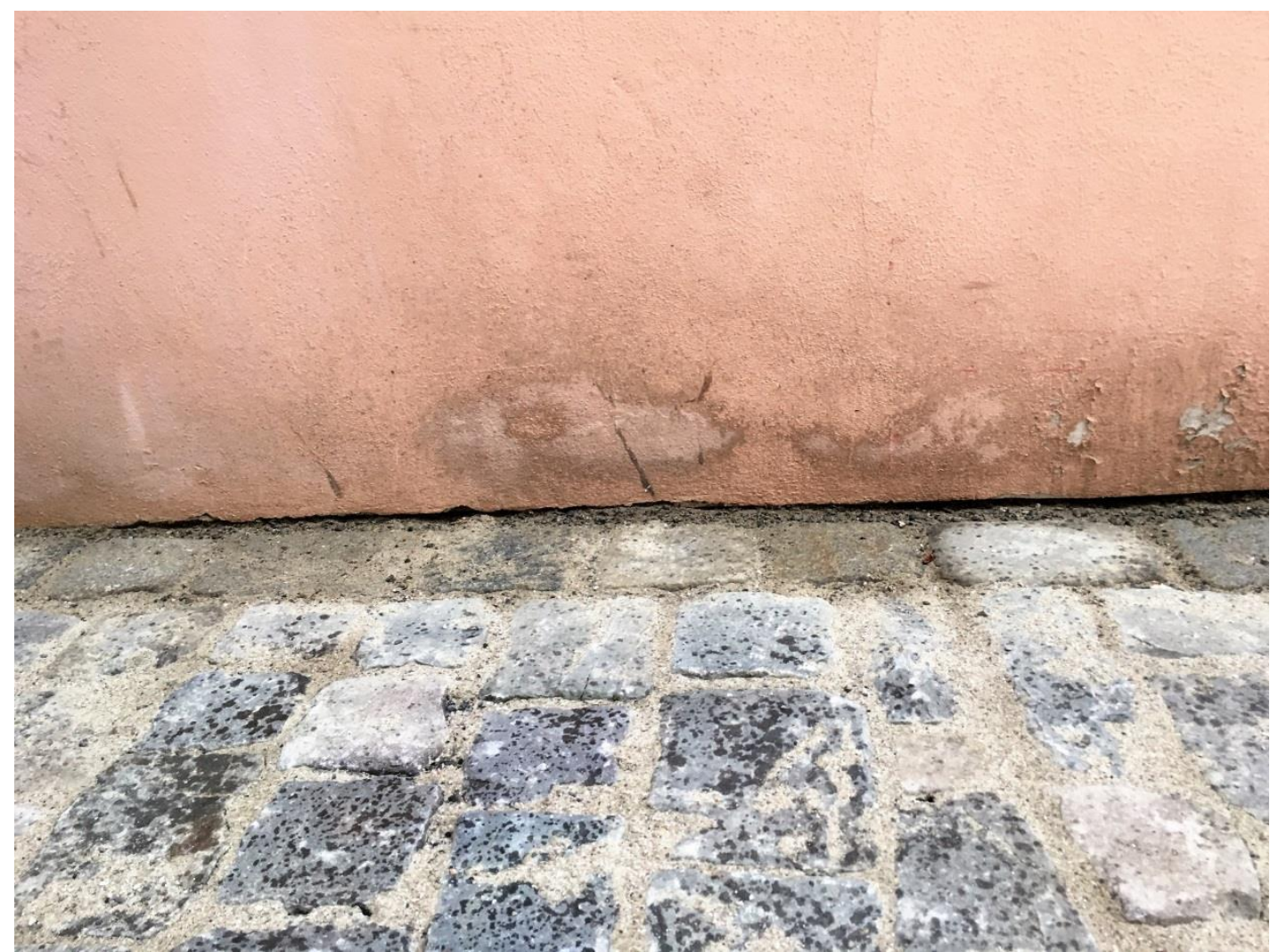

Obrázek 5: Detail fasády domu bez nopové folie ve styku s dlažbou. Provedení podle pokynů závazného stanoviska orgánu památkové péče. (zdroj: autor)

\section{Závěr}

Rekonstrukce stavby, kterou Ize u běžných staveb provést ve zjednodušeném stavebním řízení nebo na ohlášení, podléhá u nemovitých památek komplikovanému stavebnímu řízení a to i ve velmi jednoduchých případech a vždy je vyžadováno závazné stanovisko orgánu památkové péče.

Při získání tohoto stanoviska Ize stěží dodržet 30 denní lhůtu stanovenou správním rádem a to ani v prípadě že, obnovu kulturní památky budeme chápat jako stavbu mimořádně složitou, která může výkon správního rozhodnutí prodloužit až na 60 dní. Důvodem je dvojkolejnost systému památkové péče $v$ České republice, kde pro získání závazného stanoviska dotčeného orgánu památkové péče, je zároveň nezbytné získat i vyjádření oborného pracoviště Památkového ústavu, který reprezentuje druhou složku systému památkové ochrany. Př́činy jsou mimo samotnou ojedinělost historických nemovitostí nízké kapacity pracovníků odborné organizace památkové péče, nutnost koordinace a spolupráce s dalšími specialisty a omezené využití informačních technologií při vzájemné komunikaci. Dalším a možná ještě závažnějším problémem je obsah závazného stanoviska $z$ hlediska stavební odbornosti a využití současných moderních technologií.

Závazné stanovisko tedy vydává orgán památkové péče pouze $s$ ohledem na zachování aktuálně zjištěných kulturně historických hodnot avšak bez zřetele na současné znalosti stavebně technických parametrů stavby a na současné technologické zvyklosti. Tyto parametry však mohou při splnění první podmínky daleko lépe uchovat památku přištím generacím.

Východiskem $\mathrm{k}$ vyřešení této problematiky by byla změna památkového zákona a sjednocení státní správy v oblasti památkové péče, čímž by se zjednodušily a urychlily povolovací procesy při zachování památkové odbornosti a zvýšila stavební odbornost. K zefektivnění komunikace a zrychlení správního řízení by přispělo povinné použití elektronických dat v celém administrativním procesu. 


\section{References}

[1] Zákon č. 183/2006 Sb., o územním plánování a stavebním řádu (stavební zákon)

[2] Zákon č. 20/1987 Sb., o státní památkové péči, Úplný text zákona č. 20/1987 Sb., o státní památkové péči, ve znění pozdějších změn obsažených v zákonech č. 242/1992 Sb., č. 361/1999 Sb. a č. 61/2001 Sb., č. 122/2000 Sb., č. 132/2000 Sb., č. 146/2001 Sb., č. 320/2002 Sb., č. 18/2004 Sb., č. 186/2004 Sb., č. 1/2005 Sb., č. 3/2005 Sb., nálezu Ústavního soudu ČR č. 240/2005 Sb., zákona č. 186/2006 Sb., zákona č. 203/2006 Sb., zákona č. 158/2007 Sb., zákona č. 124/2008 Sb., zákona č. 189/2008 Sb., zákona č. 307/2008 Sb., zákona č. 223/2009 Sb., zákona č. 227/2009 Sb., zákona č. 124/2011 Sb., zákona č. 142/2012 Sb. a zákona č. 303/2013 Sb. podle právního stavu s účinností ke dni 1. ledna 2014 a doplněný výběrem z judikatury ke dni 18. ledna 2016

[3] Zákon č. 500/2004 Sb., Správní řád

[4] Zákon č. 225/2017 sb. Novela stavebního zákona

[5] Návrh zákona o ochraně památkového fondu a o změně zákona č. 634/2004 Sb., o správních poplatcích, ve znění pozdějších předpisů (zákon o ochraně památkového fondu), který má nahradit stávající zákon č. 20/1987 Sb., o státní památkové péči

[6] II. Závazná stanoviska dle $§ 149$ správního řádu, závěry z kontrol prováděných Památkovou inspekcíMinisterstvo kultury ČR, https://www.mkcr.cz/2-zavazna-stanoviska-dle-spravniho-radu-s-obsahem-4203

[7] Zákon o technických požadavcích na výrobky a o změně a dopInění některých zákonů 22/97 Sb

[8] Nařízení vlády, kterým se stanoví technické požadavky na vybrané stavební výrobky 163/2002 Sb.

[9] Nařízení vlády č.190/2002 Sb. ze dne 10. dubna 2002, kterým se stanoví technické požadavky na stavební výrobky označované CE

[10] OZNÁMENÍ O VYHLÁŠENÍ VÝBĚROVÉHO ŘíZENÍ na služební místo v Ministerstvu kultury, Ministerský rada č. 311 - odbor památkové inspekce, oddělení územních garantů, Č.j.: MK 68291/2017 OLZ, Datum: 8. prosince 2017 